\title{
TODA(S) LA(S) HISTORIA(S) EN UNA HISTORIA
}

BENJAMÍN FLORES HERNÁNDEZ

Departamento de Historia/UAA

Enrique Cárdenas de la Peña, La Virgen de Valvanera en México, México, edición del autor, 2001, $82 \mathrm{pp}$.

Seguramente resultará un lugar común el recordar que en cada uno de los sucesivos instantes en que se va produciendo nuestra vida, la vida de todos y cada uno de los hombres y las mujeres que hemos sido a través del tiempo, están de algún modo incluidos todo el pasado y todo el futuro de la humanidad. Este yo que soy yo ahora, en esta situación precisa en que me encuentro, por un lado presupone y viene a resumir lo que han sido y han hecho todos los demás que me precedieron: en lo biológico, para producir este ser mestizo que sepamos o no todos somos; en lo cultural, para generarme esta vocación globalizada que cada vez nos hace sentimos más directamente relacionados con las más diversas creaciones humanas de todos los tiempos y de todos los lugares; en lo espiritual, para fomentar ese sentimiento de humanidad compartida que nos aproxima entrañablemente a la comprensión de todos quienes a través de la historia han sido y están siendo, cada vez más prójimos nuestros. Y, por el otro, también contiene en sí semillas que, junto con las de los otros, germinarán en todo lo que habrá de ser en el futuro hasta el fin de los siglos: mi acción, sea la que sea, una vez consumada, ineluctable, marcará rumbos inmodificables para lo por venir. En este sentido, quien se acerca a la his- 
toria, sean cuales fueren el tiempo, el lugar y el tema de su estudio, si es que sabe hacerlo con rigor e imaginación, hasta las últimas consecuencias, llegará el momento en que topará con ese aleph del que nos hablara Jorge Luis Borges: el punto donde convergen todos los puntos, donde es posible contemplar al fin "ese objeto secreto y conjetural, cuyo nombre usurpan los hombres, pero que ningún hombre ha mirado [-pero que todos, de vez en cuando, si nos situamos en la posición adecuada, llegamos a intuir-]: el inconcebible universo".

Las reflexiones anteriores me han asaltado muchas veces en el curso de diversos trabajos de investigación histórica con los que me he involucrado a través del tiempo, en el desarrollo de los cuales un asunto inicial ha alcanzado derivaciones imprevistas y profundidades insospechadas. Una asignatura a la que me veía compelido a atender tal vez por instrucciones o por necesidades ajenas, una vez que empezaba a adentrarme en ella de repente se me aparecía como rica en matices maravillosos y, poco a poco, como decía en el párrafo anterior, como cifra y compendio de toda la experiencia y la trayectoria humanas. Los ejemplos de esto que me vienen ahora a la memoria son múltiples y van desde la historia de instituciones hasta la biografía de personajes de diferentes épocas y lugares, en cuyos curricula saltaban aleatoriamente acciones, sucedidos u ocurrencias imprevistas pero apasionantes. Mi pasión tauromáquica de toda la vida se ha visto satisfecha de la manera más increíble durante la elaboración de estudios correspondientes a materias aparentemente lo más alejadas de lo taurino. Así, al comprobar que el 19 de enero de 1943, fecha de la aparición en el Diario oficial de la Federación de la Ley del Seguro Social, corresponde a uno de los periodos más brillantes de la llamada época de oro del toreo nacional, sólo doce días anterior a la inmortal faena de Silverio Pérez a Tanguito, de Pastejé. $\mathrm{O}$ que don Bernardo de Vargas Machuca, el intrépido capitán indiano ferviente creyente en la existencia de El Dorado en las selvas amazónicas, agudo instructor de conquistadores en su Milicia indiana de 1599 y ardiente contradictor del padre Las Casas en aquellas Apologías y discursos de las conquistas occidentales que no le dejaron publicar, y al cual dediqué casi diez años de mi vida para elaborar mi tesis de doctorado, fue también y simultáneamente uno de los mejo- 
res tratadistas de la caballería de la jineta, autor de tres estupendos libros sobre el tema, en los cuales por supuesto que no dejó de referirse con pasión a las implicaciones toreras de esa forma de montar a caballo, cuya máxima culminación, "el más célebre y bizarro exercicio" de ella era, indudablemente, el alanceamiento de una res. Y, además, buen amigo de aquel apasionante don Juan de Tassis y Peralta, segundo conde de Villamediana -prologuista de uno de sus textos-, el inolvidable caballero que salió un día a torear a caballo en la Plaza Mayor de Madrid con el equívoco lema de que eran "sus amores reales" - ¿el dinero o la esposa del rey?, quedaba la duda- y que deshizo poéticamente a uno de sus adversarios con aquella descripción de la ocasión en que saliera a la arena "muy galán.../con cintillo de diamantes,/ diamantes que fueron antes/ de amantes de su mujer". No cabe dudar de ello: en la historiografía -nada más, ¿eh?, que conste- los cuernos me persiguen.

Algo por el estilo me sucedió hace seis años, en 1995, cuando el doctor Enrique Cárdenas de la Peña me pidió que lo auxiliara en la búsqueda de información acerca de un asunto que, de pronto, cuando me lo expuso por primera vez, no despertó en mí más que el vago recuerdo de antiguas lecturas de José María Marroquí y de algunos recorridos por el viejo centro de México, atrás de Palacio Nacional, por el rumbo de las calles de Uruguay y Correo Mayor, pletóricas hoy de comercio ambulante y de mercerías de árabes, no lejos del Volador donde hace dos y trescientos años -otra vez la referencia taurina- se armaban cosos temporales en ocasión de celebraciones de fiesta real y de otras temporadas completas de corridas, como aquéllas de 1769 y 1770 organizadas por el virrey marqués de Croix para obtener dinero con qué sufragar los gastos de determinadas obras públicas, y a cuya evocación dediqué mi tesis de maestría.

Hoy, que por fin pudo el doctor Cárdenas publicar por su cuenta su conferencia de la Casa de América de Madrid de octubre de 1995 en una edición elegante y bien cuidada, en papel couché semimate y con estupendas reproducciones fotográficas, rememoré la emocionante aventura que significó la rebúsqueda por muchas partes de noticias y referencias a la presencia mexicana de Nuestra Señora de Valvanera. En ella, tan inesperada como obviamente, hubieron de aparecer temas variadísimos, la 
profundización en los cuales, apenas iniciada en las páginas hoy comentadas, resulta por demás atractiva y apetitosa. Don Enrique, en sus cuartillas, con esa pericia suya de extraordinario escritor que ha sabido sublimar a través de los ya cerca de cien densos libros que ha compuesto sabe muy bien, con unas cuantas líneas acerca de cada una de ellas, dejarnos entrever mucho de lo que esos dos conceptos -Virgen de Valvanera y México-, en su unión, han significado a través del tiempo.

$\mathrm{Va}$ de cuento. La materia nos coloca en primer lugar en presencia de la devoción mariana de una específica región hispánica, la Rioja, esa que ante nuestra imaginación sobre todo resulta recordadora de un vino bravo y fino a la vez, y que está situada en la fecunda intersección de Castilla la Vieja - provincias de Burgos y Soria-, el País Vasco -Álava- y Navarra, a unos pasos también de Aragón -Zaragoza-, en plena zona de paso dentro de la ruta del Camino de Santiago, por donde toda la Europa cristiana caminó durante siglos para îr a ponerse de rodillas ante la tumba del Apóstol. Y luego avienta a nuestra consideración la manera en cómo pudo ser que tal devoción empezara en algún momento a practicarse en la
Nueva España, seguramente a partir de la presencia en el virreinato de hombres y mujeres originarios del área en cuestión. ¿Desde cuándo? ¿Desde el instante mismo del Descubrimiento, nada menos que en la carabela collombina capitana? ¿O, si no, durante la conquista comandada por Hernán Cortés a quien acompañaron, según consta, diez riojanos, entre ellos los hermanos Martín y Pedro de Ircio? Quien se acerque a los inventarios de pasajeros de Indias y a otros documentos de similar laya habrá de contestar mejor la pregunta, pero el caso es que, para el siglo XVIII, los riojanos eran de tanta significación y posibilidades en México que pudieron construir a su sola costa una estupenda capilla anexa a la iglesia de San Francisco -la cual allí perdura, aunque una guadalupana ocupa hoy el sitio que otrora tuvo en su retablo central la de Valvanera, y es punto de paso obligado para acceder a la monumental iglesia franciscana-e instalar en ella una pesada imagen escultórica de su patrona, de talla maciza e incrustada "en un nicho de plata y cristales, cuyo coronamiento consistía en una ráfaga del mismo metal con la imagen del Espíritu Santo", según la recordaba Antonio García Cubas en El libro de mis re- 
cuerdos. Y que, para organizar el culto de su madre venerada, formaron una cofradía con vida activa hasta el momento mismo de la desamortización liberal del siglo XIX que terminó con las instituciones sociales de reminiscencia corporativa de las que las cofradías representaban un ejemplo típico.

La misma historia de Nuestra Señora de Valvanera en su santuario original de ese Valle de las Venas - Vallis veniae, que no queda muy claro si aludía a venas de metales preciosos o de agua, o quizás más bien a una combinación de ambas materiasresulta apasionante, puesto que nos remite a esa religiosidad medieval europea que luego tuvo sus manifestaciones últimas en la América Hispana, y que alude a la decisión de los fieles de afirmar su fe en la voluntad de la Madre de Dios de querer permanecer a su lado para manifestarles con obras su cariño, apareciéndose en determinados sitios sagrados señalados mediante signos milagrosos, paradigmáticamente el descubrimiento de imágenes antiguas ocultadas durante la invasión musulmana y marcadas de algún modo portentoso apenas reconquistada la zona por los cristianos. No son pocas las imágenes marianas hispanoamericanas que cuentan con historias parecidas a la que se nos dice de la de Valvanera, en textos tan eminentes como el del príncipe de la lengua española Gonzalo de Berceo, riojano precisamente.

Toda una zona de la ciudad de México fue conocida por largos años como Balvanera -así, con b y no con $v$ en la tradición local-, y fueron varias las calles que a través del tiempo participaron del apelativo de un convento de monjas que no queda muy claro por qué ni desde cuándo llevó ese nombre, puesto que empezó siendo a fines del siglo XVI una casa de "recogidas" - en el nombre llevaban la fama las pobres mujeres allí recluidas- bajo la advocación de Jesús de la Penitencia y que luego, desde mediados del xviI y hasta la exclaustración del XIX fue lugar destinado a la profesión religiosa de muchachas de intachables antecedentes familiares y morales. Hoy, cosa por demás interesante, la iglesia de aquel monasterio femenino sigue abierta al culto católico pero al servicio de un rito muy particular, el maronita, propio de los descendientes de los libaneses que desde principios del siglo xx se asentaron en la zona, huyendo de la persecución turca, para dedicarse al comercio de telas y ropa 
según el patrón que el cine clásico mexicano estereotipó en El baisano Jalil, protagonizada por Joaquín Pardavé. Allí, aunque con el nombre antiguo de Balvanera, que debió venirle porque seguramente por algún tiempo contuvo en lugar central la imagen de la advocación riojana, la escultura mariana que se venera en forma principal en la actualidad es la de Nuestra Señora del Líbano.

Más y más temas apasionantes derivados del plural acercamiento al punto original. Para la historia del arte, por ejemplo, el análisis de los valores arquitectónicos del barroco estípite de la capilla anexada a San Francisco, o el de las características pictóricas y simbólicas de tres cuadros pintados en la Nueva España con el tema de Nuestra Señora de Valvanera: uno del omnipresente Miguel Cabrera existente en el Museo de Arte de Filadelfia, otro de Pedro López Calderón expuesto en el Museo Nacional de las Intervenciones en Churubusco y, el mejor y más interesante, el plasmado por Juan Correa hoy parte de las obras del Museo Franz Mayer, ubicado en el antiguo Hospital de San Juan de Dios de la ciudad de México. Por cierto que de ninguno de ellos consta su lugar de procedencia y circunstancias de realización, lo que urgiría investigar. $\mathrm{Y}$, asimismo, el hecho de que, por unos años en el siglo XIX, la Academia de Bellas Artes tuviera su sede en parte de lo que fuera el convento de Balvanera.

Baste señalar que hasta a alguna leyenda de las narradas por don Artemio del Valle Arizpe y de alguna manera relacionada con las calles aledañas al convento traslada en su texto el doctor Cárdenas, para resaltar cómo en él hace amplia relación a mucho de lo sugerido por el tema. $\mathrm{O}$ asimismo la noticia allí plasmada de la presencia de distinguidos riojanos -o cuando menos miembros de la cofradía establecida para venerar a la patrona logroñesa, precisamente fundada "por los naturales y originarios de la muy noble y muy leal Nación de Rioja"- devotos de la Virgen de Valvanera en el virreinato novohispano y relacionados con esa hermandad: Juan Crisóstomo de Barroeta, regente del Real Tribunal de Cuentas por 1770, el conde de Xala, el marqués de Sierra Nevada y, tal vez el más significativo, el ilustrísimo e ilustrado arzobispo Francisco Xavier de Lizana y Beaumont, riojano de Arnedo y particular siervo de "nuestra soberana patrona", el cual incluso ejerció el virreinato de la 
Nueva España de julio de 1809 a mayo de 1810.

Innumerables, pues, los asuntos derivados del enunciado que da título a la conferencia hoy convertida en libro a los que su autor alude con noticias a veces instantáneas, fugaces, pero que dejan la puerta abierta a la aventura inquisitiva de los interesados. Lo cual no quiere decir que no haya otros más que a algún engolosinado pudieran presentársele. Tales las arterias caudalosas que desde el Valle de las Venas irrigan España, la América Española y el ancho mundo de sangre viva, proponiendo al curioso indagador cuestiones interesantísimas. Se me ocurren por lo pronto, enunciativa que no exhaustivamente: para una historia de las religiones, la manera de expresarse y de vivir lo sagrado implícita en la devoción valvavenera desde sus raíces medievales y hasta la actualidad, así en la zona de origen de la advocación como en los diferentes sitios adonde se ha trasplantado -hace falta completar el inventario mundial de la expansión del culto, por ejemplo-; para una historia social, la migración de los riojanos por los caminos universales, llevando siempre consigo sus tradiciones, su cultura, su vinculación con el terruño; para una historia del arte, el cabal índice de las representaciones plásticas de la historia primitiva de la aparición y descubrimiento de la imagen... Algún tema concreto, así, pensado de repente: el arribo de riojanos hasta las latitudes mexicanas, estudiado con rigor, y el sitio que para ellos ha guardado, como símbolo de comunicación permanente con la tierruca, la devoción a la de Valvanera.

Pero, en fin, ésas no son sino unas cuantas ideas surgidas de la sugerente lectura del librito de Enrique Cárdenas de la Peña, por lo demás tan serio, bien pensado y hermosamente compuesto como los demás por él acabados, referentes a materias tan variadas como la navegación, la medicina, las comunicaciones, las entidades regionales o las específicas trayectorias individuales, y que sigue firme, investigando y redactando en la actualidad, bien dispuesto a seguir presentándonos nuevos frutos de su trabajo de ejemplar historiador.

En verdad que uno de los más ciertos motivos de orgullo que como aficionado a las artes de Clío puedo yo tener es el de que, desde hace ya veintiocho años, haya él querido, de vez en cuando, contar con mi tan sencilla cuanto entusiasta y bien dispuesta colaboración. 
